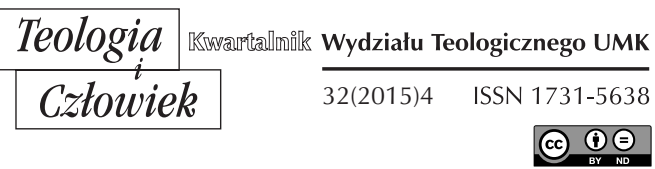

PIOTR WÓJCIK*

DROHICZYN

\title{
THE STATUS OF THE CLONED HUMAN EMBRYO IN ITALIAN BIOETHICAL LITERATURE
}

DOI: http://dx.doi.org/10.12775/TiCz.2015.049

The rapid development of cloning and especially of human cloning has given rise to many discussions on the status of the human embryo. Finding the answer to the question of whether or not the embryo is a human person from the first moments of its life would resolve much of the controversy that has developed in the field of biomedicine.

In the debate about the human being and about his or her humanity in the prenatal stage, many biological and philosophical terms are used, for example: zygote, pre-embryo, embryo, foetus, human being, human person, soul, etc. Among the interpretations of the development of the human embryo there are different theories or criteria for what constitutes

* Piotr Wójcik (Drohiczyn) - priest, BeD, presbyter of the Drohiczyn Diocese, theologian and bioethicist, graduated from the Papal Department of Theology in Warsaw, he took his $\mathrm{PhD}$ degree in bioethics in Ateneo Pontificio Regina Apostolorum, Rome, lecturer in Major Diocesan Seminary in Drohiczyn. In his scientific work he concentrates on clinical bioethics and embryology; he is also involved in the research on new medical techniques in the context of human dignity. 
humanity, which we can divide into two main types: 1. A Human from the beginning, 2. A Human at a later phase.

\section{A HUMAN FROM THE BEGINNING}

In order to demonstrate the personal status of the embryo, reference is usually made to the following arguments: the genetic argument; the argument of continuing development; the argument of identity.

\section{THE GENETICS ARGUMENT}

The cloned human embryo contains the chromosomes originating from the nucleus that belong to the human species, which means that the embryo is also a living being belonging to the human species.

P. Ide emphasises that: "embryology and genetics show us that from the moment of conception the embryo is: 1 . a being with a specific nature, in this case a human nature, different from any other animals and living species, for example, from that of other pongids (chimpanzees, gorillas, orang-utans); an individual being, unique and distinct from any other, individual and original in its genome and in its phenotypical expression."

We can ask ourselves: how does one posit this question with the cloned embryo, which possesses the same genotype as the donor? J. Woo Jung responds to this question, saying, "this reality does not diminish its individuality: the vital process of the cloned embryo proceeds, in an autonomous way, under the control of the genes through the interaction between the nucleus and the egg cell and between the embryo and the external environment, independently of the donor." ${ }^{2}$ There are other

1 P. Ide, "L'embrione umano è persona? Status questionis e determinazione," [in:] L'embrione umano nella fase del preimpianto. Aspetti scientifici e considerazioni bioetiche. Atti della dodicesima assemblea generale della Pontificia Accademia per la vita, eds. E. Sgreccia, J. Laffitte, Vatican City 2007, p. 251, our translation.

2 Cf. J.W. Jung, “Clonazione per nuclear transfer: problemi bioetici," [in:] Biotecnologia ed etica: cellule staminali e clonazione umani, ed. A. Garcia Gomez, Rome 2008, pp. 266-267. 
elements that influence the identity of the cloned embryo, for example, biological or environmental mutations. ${ }^{3}$

\section{THE ARGUMENT OF CONTINUING DEVELOPMENT}

After the activation of the cloned embryo that has been produced though nuclear transfer technology, development proceeds without interruptions. It passes through many stages and functionally keeps its development oriented in the direction of the final form. ${ }^{4}$

The human being has in the process of his or her development some fixed biological properties, which are illustrated in detail by geneticists in various operations: "coordination, that is, to represent a functionally organized unit according to a goal set and pursued independently thanks to instructions contained in the genetic program of the organism; continuity, or rather, the fact that in each moment of development the same individual who will be changing is concerned; gradualness, namely, the progressive self-constituting, through the various phases of growth and change, of the final form of the individual, according to its own identity, individuality, and unity." ${ }^{5}$

A. Giuli adds that, "human development implies, from the beginning, an intense molecular and cellular cooperation according to a defined plan thanks to the genetic information contained in the genome and thanks to the complex pattern of genetic activation characteristic of each species, which gives guidance and unity of growth. The human embryo will therefore evolve as a unique system, integrated and organized, and thus, it can never be reduced to the sum of the parts that compose it." 6

3 Cf. M. Wagnez, Clonazioni. L'individuo, le cellule e i geni, Bari 2009, p. 103.

${ }^{4}$ Cf. G.M. Carbone, Le cellule staminali, Che cosa sono? A cosa Servono? E lecito usarle?, Bologna 2005, pp. 17-19.

${ }^{5}$ C. Navarini, Procreazione assistita? Le sfide culturali: selezione umana o difesa della vita, Casale Monferrato 2005, pp. 55-56.

${ }^{6}$ A. Giuli, Inizio della vita umana individuale Basi biologiche e implicazioni bioetiche, Rome 2005, p. 275. 
Instead, the English report on fertilization and human embryology, the "Warnock Report," says that, "as soon as the process is started, there is no one part of the development process that is more important than another; everything is part of a continuous process, and if each stage does not happen normally at the right time and in the correct order, further development ceases [...] Thus, biologically one cannot identify a single stage in the development of the embryo beyond which the embryo in vitro should not be kept alive."

\section{THE IDENTITY AND INDIVIDUALITY ARGUMENT}

The human being, throughout his or her existence always remains the same being. The individual nature of the zygote or early embryo is supported by the genetics argument. ${ }^{8}$ From available data, it is possible to state that the entry of the spermatozoon into the oocyte is a biological event that triggers the molecular and metabolic chain of events that characterize the life cycle of a new organism and that will end with its death. ${ }^{9}$

It should be added that with the scientific data acquired thus far, the cloned embryo, both animal and human, produced through the technique of nuclear transfer, has the same fundamental properties when it is activated that are observed in the fertilized embryo. ${ }^{10}$ "According

7 Department of Health and Social Security, Report of the Committee of Inquiry into Human Fertilization and Embryology, London 1984; Italian translation cited in: A. Serra, R. Colombo, "Identità e statuto dell'embrione umano: il contributo della biologia," [in:] Identità e statuto dell'embrione umano, Vatican City 1998, p. 157.

${ }^{8}$ Cf. P. Braude, V. Bolton, S. Moore, "Human gene expression first occurs between the four- and eight-cell stages of preimplantation development," Nature 332 (1988) no. 6163, pp. 459-461.

9 Cf. A. Giuli, Inizio della vita umana individuale, p. 260; G.M. Carbone, Le cellule staminali, pp. 20-21; G. Sica, "Lo sviluppo dell'embrione preimpianto," [in:] L'embrione umano nella fase del preimpianto. Aspetti scientifici e considerazioni bioetiche. Atti della dodicesima assemblea generale della Pontificia Accademia per la vita, eds. E. Sgreccia, J. Laffitte, Vatican City 2007, pp. 132-141.

${ }^{10}$ Cf. A. Serra, R. Colombo, Identità e statuto dellembrione umano: il contributo della biologia, pp. 110-111. 
to a precise ontogenetic law of development, the individual human will grow through stages of increasing cellular complexity, and malleable nature and early cellular plasticity will gradually shrink to express through processes of cellular division, growth, and differentiation (and in continuous interaction with the environment) - the phenotypical characteristics of an individual multicellular adult." ${ }^{11}$

The embryo is always the same and identical being with its own identity, which is built, in an autonomous way, while passing through stages that are, in quantitative terms, increasingly complex. ${ }^{12}$

From the biological data available today, it is deduced that the embryo from the time of fertilization is a new human individual which begins its own life cycle.

From a philosophical standpoint, it can be said that the embryo is not a potentiality to become a human being, like the egg and the sperm, or in this case, the egg and the nucleus. It is, rather, a being "in act." It develops into a fully formed human being. It is a human being that has all its potentialities and will actuate them in its development. ${ }^{13}$

Giuseppe de Rosa states: "if the embryo, from the first moment of its existence as unicellular embryo, has its individuality, its internal law of development that will lead without resolution of continuity to being a completely developed human, and therefore has an identity that does not change with its becoming a complete human (the embryo that begins to develop and the developed human are the same being), one must say that, just as the developed human is a human person, so the embryo from the beginning of its development is also a human person, even if it is in the state of developing." 14

Therefore, the cloned human embryo is a person. Even if its capacity cannot be observed in a complete way.

\footnotetext{
${ }^{11}$ Cf. A. Giuli, Inizio della vita umana individuale, p. 275.

${ }^{12}$ Cf. J.W. Jung, Clonazione per nuclear transfer: problemi bioetici, p. 265.

${ }^{13}$ Cf. R. Lucas Lucas, Antropologia e problemi bioetici, Milan 2001, pp. 92-94.

14 G. De Rosa, L’uomo la sua natura il suo destino, Rome 2007, p. 129.
} 


\section{A HUMAN AT A LATER PHASE}

There are some scientists who offer opinions to the effect that the zygote and the embryo in the first hours of life would not be an individual human. They say that it is instead an aggregate of cells of the human species and, before implantation in the uterus, it would be a "cluster of cells" or a "coil of matter." Genetic individuality and human individuality would therefore be distinguished. ${ }^{15}$

\section{THE CRITERIA OF BIOLOGICAL DEVELOPMENT}

According to the reductionist tendency, the beginning of the human person is postponed. There are different moments of embryonic development considered significant for drawing a line of separation between human and personal beings. The two principal texts of reductionist thought concern the concept of individuality and the moment of formation of the structures necessary for the exercise of the activity specific to humans: rationality.

\section{THE "TOTIPOTENCE" ARGUMENT}

Some say that a complete living individual is a differentiated organism that is composed of various organs ordered to one or more functions. Until the eight-cell stage, the embryo is composed of totipotent cells, that is, cells capable of becoming any organ. According to some scientists the embryo becomes an individual only when the cells that compose it are no longer totipotent. ${ }^{16}$ As A. Serra and R. Colombo note, "totipotence" is an extraordinary dynamic property of the zygote and of the cells of the very early embryo. ${ }^{17}$ The embryo in this phase

15 Cf. A. Serra, R. Colombo, Identità e statuto dell'embrione umano: il contributo della biologia, p. 147.

${ }^{16}$ Cf. G.M. Carbone, Lembrione umano: Qualcosa o Qualcuno?, Bologna 2005, p. 26.

17 Ibid. 
has the capacity of developing in the extraembryonic coelom because the information contained in the genetic code of the cell is also completely accessible; if the totipotent cells are separate from the embryo in development for experimental purposes, they are capable of giving rise to a new, complete individual. ${ }^{18}$

The totipotence argument is strengthened by the possibility of monozygotic twinning. ${ }^{19}$ This phenomenon, according to some researchers, incontrovertibly demonstrates that the early embryo, as long as it has the ability to give rise to two or more embryos, cannot be a single individual. ${ }^{20}$

In order to clarify the issue, we must say that, "in an early embryo from the fourth to fifth cellular cycle, only an error or a disruptive event may be able to isolate the cell whose genome, according to the plan of differentiation, has not yet suffered restriction. In such a case these cells can be capable - given the necessary conditions - of beginning their life cycle. Then, and only then, would this cell or group of cells be considered a new individual to another individual in its precise stage of development.

Thus, totipotence does not oppose individuality. Totipotent cells can be part of an individual without destroying its individuality." ${ }^{21}$

\section{THE IMPLANTATION ARGUMENT}

About six days after fertilization, the embryo adheres to the uterine wall, indicating the process of implantation, which is complete within twelve to fourteen days of development. ${ }^{22}$ This moment is very important

18 Cf. A. Giuli, Inizio della vita umana individuale, p. 123.

19 Cf. P. Ide, L'embrione umano è persona? Status questionis e determinazione, p. 242; M.L. Di Pietro, E. Sgreccia, Procreazione assistita e fecondazione artificiale tra scienza, bioetica e diritti, Brescia 1999, p. 141.

20 Cf. G.M. Carbone, L'embrione umano: Qualcosa o Qualcuno?, p. 27; L. Ciccone, Bioetica. Storia, principi, questioni, Milan 2003, p. 65.

${ }^{21}$ A. Serra, R. Colombo, Identità e statuto dellembrione umano: il contributo della biologia, p. 153.

${ }^{22}$ Cf. H. Bartel, Embriologia, pp. 100-106. 
because it marks the beginning of development of the embryonic tissues, followed by the formation of organs and tissues.

Some scientists claim that implantation would be the beginning of true embryonic growth, allowing one to distinguish the cells destined to form the embryo from those that compose the extraembryonic annex, which would define the moment of beginning of human individuality. ${ }^{23}$

The implantation would be the beginning of close communication between the embryo and the maternal organism, that is, of the mother-foetus relationship, marking the boundary of the definition of the person. ${ }^{24}$

Francesco D'Agostino together with Laura Palazzani recall that this theory has been criticized both scientifically and philosophically. On the scientific level, it has been revealed that even before implantation, a biochemical relationship with the embryo and the mother is established, as for the philosophical level, it has been observed that said relationship, though an indispensable element for embryonic development, does not constitute the existence of the being, but rather it presupposes it: there is no a relationship (even physiological) if there is not first a being that is related to something else. ${ }^{25}$

In the second week of embryonic development, that is, through the fourteenth day, the primitive streak forms. From this moment the three distinct embryonic layers are established - the ectoderm, the mesoderm, and the endoderm - from which originate the tissues and organs of the embryo.

Some claimed that before this date, there is not a human individual but a "pre-embryonic being." 26

${ }^{23}$ Cf. M.L. Di Pietro, E. Sgreccia, Procreazione assistita e fecondazione artificiale tra scienza, bioetica e diritti, p. 141; G.M. Carbone, L'embrione umano: Qualcosa o Qualcuno?, p. 28.

${ }^{24}$ Cf. L. Palazzani, "I significati del concetto filosofico di persona e implicazioni nel dibatto bioetico e biogiuridico attuale sullo statuto dell'embrione umano," [in:] Identità e statuto dell'embrione umano, Vatican City 1998, p. 62-63; A. Giuli, Inizio della vita umana individuale, p. 128.

25 F. D’Agostino, L. Palazzini, Bioetica. Nozioni fondamentali, Brescia 2007, p. 77 .

${ }^{26}$ Cf. A. Giuli, Inizio della vita umana individuale, p. 131. 


\section{THE CEREBRAL ACTIVITY ARGUMENT}

The third opinion stresses that we are not an individual until the nervous system is formed and cerebral life begins. The formation of the central nervous system is the boundary of personal subjectivity identified by utilitarian theory. The scientists with this conception exclude from personal status all those who are not yet equipped with perceptiveness. ${ }^{27}$

Some, however, identify the beginning of personal subjectivity in the phase of the formation of the cerebral cortex. What we find here is a rationalistic view of the person which considers essential the ascertainment of the presence of the neurological conditions that allow for the organic development of intelligence. ${ }^{28}$ "Therefore, the life of the human being, according to this perspective, coincides with the life of the cerebral cortex. Life is, in other words, a continuous spectrum, the boundaries of which are distinctively identifiable: the beginning coincides with the appearance of cerebral life in utero, where the appearance is verified through the revelation and observation of the presence of an activity of coordination of the organism (this concerns an individual boundary in different points and moments in development, by different authors: for some, the eighth week of gestation, the moment of the formation of the first neural circuits; for others between the twentieth and the twenty-eighth week of fertilization, the moment of the connection between the cortex and thalamus and the synaptic integration of the nervous system); the end is identified with the observation of brain death (however, it should be noted, of brain death of the higher functions, not of total brain death that also includes the death of the lower subcortical functions of the primitive brain, responsible for the regulation of vegetative activity). Before development and after the destruction of the cerebral cortex there are only cells, tissues, organs or systems of organs, without any coordination: in other words, there is 'human' life, but not the life of a human being." 29

${ }^{27}$ Cf. G.M. Carbone, Lembrione umano: Qualcosa o Qualcuno?, p. 29.

28 Cf. A. Giuli, Inizio della vita umana individuale, p. 134.

${ }^{29}$ L. Palazzani, Il concetto di persona tra bioetica e diritto, Turin 1996, pp. 127-128; J.M. Goldening, “The brain-life theory: towards a consistent biological definition of humanness," Journal of Medical Ethics 11 (1985), pp. 198-204; A. Serra, R. Colombo, Identità e statuto dell'embrione umano: il contributo della biologia, pp. 155. 


\section{THE ARGUMENT OF THE VIABILITY OF THE FOETUS}

The "viability of the foetus" indicates its capacity for independent existence, of autonomous life and concerns the stage of development in which the foetus is capable of surviving outside of the mother's uterus. ${ }^{30}$

This statement has had a certain resonance, particularly in the juridical context. The motivation for this was the decision of the Supreme Court of the United States in 1973, which permitted the practice of voluntary abortion before the viability of the human foetus, indicating with this stage an objective parameter to talk about the full humanity of the foetus. ${ }^{31}$

\section{THE CONSCIOUSNESS ARGUMENT}

"The exercise of rationality, the capacity for consciousness and self-awareness, are the characteristic elements of a personal existence that would begin or end at the moment of acquisition or loss of these capabilities (that cannot definitely belong to the embryo and the foetus) by the living individual. Following this direction are the theses of $\mathrm{M}$. Tooley, P. Singer, D. Callahan, and H. Engelhardt, in which they state that membership in the human species (according to these authors the human being, as a biological being, exists from the time of fertilization) it is not sufficient criterion for attributing personhood." 32

According to P. Singer a person is any rational and self-aware being, even if it is not part of the species of homo sapiens, while every being who is not rational and self-aware is not a person, even if it is a member of the species homo sapiens. This means that some animals that are conscious are persons, we can think, for example, of chimpanzees and gorillas, while

${ }^{30}$ Cf. A. Giuli, Inizio della vita umana individuale, p. 143.

${ }^{31}$ Cf. A. Zaitchik, "Viability and the morality of abortion," Philosophy and Public Affairs 10 (1989), no. 1, pp. 18-26; L. Palazzani, Il concetto di persona tra bioetica e diritto, pp. 151-152; A. Giuli, Inizio della vita umana individuale, p. 134.

${ }^{32}$ A. Giuli, Inizio della vita umana individuale, p. 146. 
human beings who are not conscious and are incapable of rationality are not persons, like beings who are mentally ill or mentally handicapped. ${ }^{33}$

Hugo Tristram Engelhard similarly states that, "not all human beings are persons. Foetuses, infants, the seriously mentally handicapped, and those who are in a coma without hope of recovery are examples of non-personal humans. They are not primary participants in the moral enterprise. Only human persons have this status." 34

Giuseppe de Rosa stresses that there is an error in these conceptions. "It lies in defining the person by his or her acts, rather than by the substrate (the 'substance') from which those acts come and are made possible. It is that in failing to see that self-awareness and rationality and any other act that qualifies the person - are based on something substantial and permanent, which exists even when the acts are not there or are no longer there." ${ }^{35}$

\section{THE SOCIAL CRITERION}

Some scientists suggest defining the person based on recognition by others, that is, the personal being is a social status conferred by others, a given entity is a person only if it is recognized as such by other persons; the person exists only in relation to other persons because personhood has a relational character. ${ }^{36}$

THE ACCEPTANCE OF THE CONCEIVED LIFE BY THE MOTHER; BY PARENTS; BY SOCIETY

"Non-personal" human beings, according to Engelhardt, do not have an intrinsic value, but rather have value only with respect to per-

33 R. Spaemann, Persone. Sulla differenza tra "qualcosa" e "qualcuno" a cura di Leonardo Allodi, Rome-Bari 2005, pp. 230-232; G. De Rosa, L’uomo la sua natura il suo destino, pp. 116-117; L. Palazzani, Il concetto di persona tra bioetica e diritto, pp. 155-170.

${ }^{34}$ H.T. Engelhardt, Manuale di Bioetica, Milano 1991, p. 126.

${ }^{35}$ G. De Rossa, L'uomo la sua natura il suo destino, p. 120.

${ }^{36}$ Cf. A. Giuli, Inizio della vita umana individuale, p. 149. 
sons (in the sense that their value depends on the value attributed to them by other persons), and only with respect to society, in the sense that society should establish which consideration should be attributed to them based on the relationship between the benefits that involve them continuing to live and the economic and social burdens that their survival requires. ${ }^{37}$

The embryo becomes personal only when the mother, who has the baby in her womb, accepts it; if instead she does not, or chooses an abortion, then the child should not be treated as a person because this value has not been attributed to it. The same thing happens with parents, who may decide, if the embryo is not wanted or has been conceived as a result of violence, that it would not be considered a human person. ${ }^{38}$

THE APPROVAL OR DISAPPROVAL OF HUMANITY ON ACCOUNT OF SOCIETY AND MATERIAL CONCERNS

The society making the calculation between costs and benefits could assess that, "it is more advantageous for the persons and for all society for the foetuses to live and to educate their children rather than abolish them, when in the rearing of the children important virtues for the welfare of the persons and of society are strengthened. It can instead assess that the advantage that comes from allowing an unborn human, or one who is no longer personal, to live is below the social and economic burdens that it entails: in this case, the human beings lose any value and can be suppressed by society." 39

\section{CONCLUSION}

Nevertheless, not even the noblest objectives may decide on the admissibility of any action whose object consists of a human being. The measure of admissibility of this action is the respect of the dignity

${ }^{37}$ Cf. G. De Rosa, L’uomo la sua natura il suo destino, p. 115.

${ }^{38}$ Cf. A. Giuli, Inizio della vita umana individuale, pp. 149-151.

${ }^{39}$ G. De Rosa, L’uomo la sua natura il suo destino, p. 116, our translation. 
of the human person at each stage of its development, from the first moments of life. Reflecting on cloning we arrive at the conclusion, which independently of the scope for which cloning is used, that this technique carries with it a lack of respect for the dignity of the human person. Cloning is an activity that always carries with it the calling of a new human being into life, outside of conjugal love, in a way that is absolutely deprived of the personalistic dimension. The use of this procedure involves the fact of exposing the human person to the risk of life or risk of the loss of health.

Streszczenie. Status klonowanego embrionu we włoskiej literaturze bioetycznej. Próby klonowania podjęte na zwierzętach, a zwłaszcza te w kontekście człowieka wywołały bardzo liczne dyskusje na temat statusu embrionu ludzkiego. Udzielenie odpowiedzi na pytanie, jaki status ma embrion od pierwszych chwil swojego istnienia, pozwoliłoby na wyeliminowanie wielu kontrowersji. W dyskusji toczącej się na temat człowieczeństwa na wczesnym etapie rozwoju używa się zarówno terminów biologicznych, jak i filozoficznych. Wśród interpretacji danych dotyczących rozwoju embrionu ludzkiego powstałego w procesie klonowania w literaturze włoskiej znajdują się różne teorie i kryteria jego człowieczeństwa. Można je podzielić na dwie części: człowiek od początku oraz człowiek w fazie późniejszej. W pierwszej części przytaczane są takie argumenty, jak: genetyczny, ciągłości rozwoju, indywidualności i tożsamości. W drugiej natomiast: totipotencja, implantacja w macicy, aktywność mózgu, świadomość, akceptowalność przez matkę i społeczeństwo.

Słowa kluczowe: status embrionu; klonowanie; człowiek.

Abstract. The Status of the Cloned Human Embryo in Italian Bioethical Literature. The attempts of cloning on animals, especially those in the context of human cloning, provoked numerous discussions on the status of human embryo. Giving the answer to the question concerning the status of embryo since its very first moments of its existence could eliminate many controversies. When discussing humanity at its early stage of development many biological and philosophical terms are used in Italian literature. Among the interpretations of data concerning the development of human embryo created in the process of cloning, there are many theories and criteria of its humanity. They may be divided into two parts: a human being from the beginning and a human being at a later stage. The first stage quotes such arguments as genetics, the continuity of development, individuality, and identity. Whereas the second includes: totipotence, implantation in womb, brain activity, awareness, being accepted by mother and society.

Key words: status of embryo; cloning; human being. 
